\title{
Front Matter: Volume 11255
}

, "Front Matter: Volume 11255," Proc. SPIE 11255, Colloidal Nanoparticles for Biomedical Applications XV, 1125501 (26 March 2020); doi:

$10.1117 / 12.2569679$

SPIE. Event: SPIE BiOS, 2020, San Francisco, California, United States 


\title{
Colloidal Nanoparticles for Biomedical Applications XV
}

\author{
Marek Osiński \\ Antonios G. Kanaras
}

Editors

1-3 February 2020

San Francisco, California, United States

Sponsored by

SPIE

Cosponsored by

Ocean Optics, Inc. (United States)

Published by

SPIE 
The papers in this volume were part of the technical conference cited on the cover and title page. Papers were selected and subject to review by the editors and conference program committee. Some conference presentations may not be available for publication. Additional papers and presentation recordings may be available online in the SPIE Digital Library at SPIEDigitalLibrary.org.

The papers reflect the work and thoughts of the authors and are published herein as submitted. The publisher is not responsible for the validity of the information or for any outcomes resulting from reliance thereon.

Please use the following format to cite material from these proceedings:

Author(s), "Title of Paper," in Colloidal Nanoparticles for Biomedical Applications XV, edited by Marek Osiński, Antonios G. Kanaras, Proceedings of SPIE Vol. 11255 (SPIE, Bellingham, WA, 2020) Seven-digit Article CID Number.

ISSN: $1605-7422$

ISSN: $2410-9045$ (electronic)

ISBN: 9781510632738

ISBN: 9781510632745 (electronic)

Published by

SPIE

P.O. Box 10, Bellingham, Washington 98227-0010 USA

Telephone +1360 6763290 (Pacific Time) · Fax +1 3606471445

SPIE.org

Copyright @ 2020 , Society of Photo-Optical Instrumentation Engineers.

Copying of material in this book for internal or personal use, or for the internal or personal use of specific clients, beyond the fair use provisions granted by the U.S. Copyright Law is authorized by SPIE subject to payment of copying fees. The Transactional Reporting Service base fee for this volume is $\$ 21.00$ per article (or portion thereof), which should be paid directly to the Copyright Clearance Center (CCC), 222 Rosewood Drive, Danvers, MA 01923. Payment may also be made electronically through CCC Online at copyright.com. Other copying for republication, resale, advertising or promotion, or any form of systematic or multiple reproduction of any material in this book is prohibited except with permission in writing from the publisher. The CCC fee code is $1605-$ $7422 / 20 / \$ 21.00$.

Printed in the United States of America by Curran Associates, Inc., under license from SPIE.

Publication of record for individual papers is online in the SPIE Digital Library.

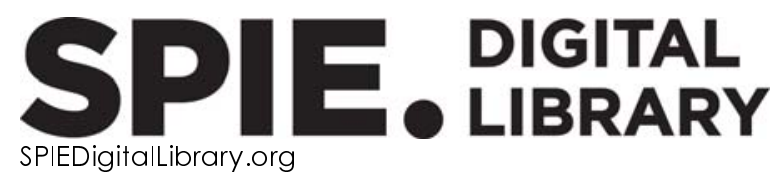

Paper Numbering: Proceedings of SPIE follow an e-First publication model. A unique citation identifier (CID) number is assigned to each article at the time of publication. Utilization of CIDs allows articles to be fully citable as soon as they are published online, and connects the same identifier to all online and print versions of the publication. SPIE uses a seven-digit CID article numbering system structured as follows:

- The first five digits correspond to the SPIE volume number.

- The last two digits indicate publication order within the volume using a Base 36 numbering system employing both numerals and letters. These two-number sets start with 00, 01, 02, 03, 04, 05, 06, 07, 08, 09, OA, OB ... 0Z, followed by 10-1Z, 20-2Z, etc. The CID Number appears on each page of the manuscript. 


\section{Contents}

$\begin{aligned} \vee & \text { Authors } \\ \text { vii } & \text { Conference Committee }\end{aligned}$

BIOMEDICAL APPLICATIONS OF PLASMONIC NANOPARTICLES I

$1125504 \quad$ VNB-mediated endosomal escape triggers robust gene silencing in human cell lines [1 1255-3]

NANO-BIO COMPLEXES AND ASSEMBLIES

1125509 Competitive binding of gold nanospheres and nanorods on DNA origami substrates (Invited Paper) [1 1255-8]

BIOMEDICAL APPLICATIONS OF PLASMONIC NANOPARTICLES II

11255 OC Considering variables in ultra-short laser pulses to release nucleic acids from the surface of gold nanoparticles [1 $11255-12]$

NANOPARTICLE CHARACTERIZATION TECHNIQUES

$11255 \mathrm{OH} \quad$ Universal and quantitative measure of colloidal stability of plasmonic nanoparticles via comprehensive stability parameter method [1 1255-17]

NP APPLICATIONS IN BIOSENSING AND BIOIMAGING I

11255 OK Engineering functional nanoparticles for delivery in cells [1 1255-20]

NP APPLICATIONS IN BIOSENSING AND BIOIMAGING III

11255 OR Brightness-equalized heavy metal-free quantum dots for biosensing and imaging [1 1255-27]

11255 OS Lipoic acid as anchoring groups and reactive sites on nanoparticles coated with multicoordinating polymers [1 $1255-28]$ 
APPLICATIONS OF NANOPARTICLES IN CANCER THERANOSTICS

11255 OV Dual-drug loaded phase-changing nanodroplets for image-guided tumor therapy [1 1255-31]

POSTER SESSION

$1125510 \quad$ Spectral engineering of UV luminescence of upconverting nanoparticles [1 1255-36]

iv

Proc. of SPIE Vol. 11255 1125501-4

Downloaded From: https://www.spiedigitallibrary.org/conference-proceedings-of-spie on 26 Apr 2023 Terms of Use: https://www.spiedigitallibrary.org/terms-of-use 


\title{
Authors
}

Numbers in the index correspond to the last two digits of the seven-digit citation identifier (CID) article numbering system used in Proceedings of SPIE. The first five digits reflect the volume number. Base 36 numbering is employed for the last two digits and indicates the order of articles within the volume. Numbers start with $00,01,02,03,04,05,06,07,08,09,0 A, 0 B \ldots . .0 Z$, followed by 10-1Z, 20-2Z, etc.

\author{
Alexaki, Konstantina, OK \\ Braeckmans, Kevin, 04 \\ Brans, Toon, 04 \\ Brown, Tom, OK \\ Bui, Hieu, 09 \\ Dawson, Peter, 10 \\ Dennis, Allison M., OR \\ De Smedt, Stefaan, 04 \\ De Vos, Winnok H., 04 \\ Díaz, Sebastián A., 09, 0C \\ El Sagheer, Afaf H., OK \\ Fontana, Jake, 09 \\ Fraire, Juan C., 04 \\ García-Díaz Barriga, Gerardo, 04 \\ Hastman, David A., OC \\ Houthaeve, Gaëlle, 04 \\ Jandhyala, Sidhartha, OV \\ Jin, Zhicheng, OS \\ Kanaras, Antonios G., OK \\ Kapur, Anshika, OS \\ Klein, William P., 09 \\ Kong, Victoria H., OR \\ Kyriazi, Maria Eleni, OK \\ Lee, Somin Eunice, $\mathrm{OH}$ \\ Lin, Wei-Kuan, $\mathrm{OH}$ \\ Liu, Jing, 04 \\ Luke, Geoffrey P., OV \\ Mathur, Divita, 09 \\ Mattoussi, Hedi, OS \\ Medintz, Igor L., 09, 0C \\ Naciri, Jawad, 09 \\ Nguyen, Vina, 10 \\ Oh, Eunkeu, 09 \\ Raemdonck, Koen, 04 \\ Raes, Laurens, 04 \\ Romanowski, Marek, 10 \\ Spatarelu, Catalina-Paula, OV \\ Stremersch, Stephan, 04 \\ Toufanian, Reyhaneh, OR \\ Wang, Wentao, OS
}


Proc. of SPIE Vol. 11255 1125501-6 Downloaded From: https://www.spiedigitallibrary.org/conference-proceedings-of-spie on 26 Apr 2023
Terms of Use: https://www.spiedigitallibrary.org/terms-of-use 


\title{
Conference Committee
}

\author{
Symposium Chairs
}

Jennifer K. Barton, The University of Arizona (United States)

Wolfgang Drexler, Medizinische Universität Wien (Austria)

Conference Chairs

Marek Osiński, The University of New Mexico (United States)

Antonios G. Kanaras, University of Southampton (United Kingdom)

Conference Program Committee

Ramón Alvares-Puebla, Universidade de Vigo (Spain)

Jacob M. Berlin, City of Hope Beckman Research Institute

(United States)

James B. Delehanty, U.S. Naval Research Laboratory (United States)

Allison M. Dennis, Boston University (United States)

Laura Fabris, Rutgers, The State University of New Jersey

(United States)

Hedi Mattoussi, Florida State University (United States)

Igor Medintz, U.S. Naval Research Laboratory (United States)

Jay L. Nadeau, McGill University (Canada)

Kelly L. Nash, The University of Texas at San Antonio (United States)

Wolfgang J. Parak, Universität Hamburg (Germany)

Francisco Raymo, University of Miami (United States)

Ute Resch-Genger, Bundesanstalt für Materialforschung und -prüfung (Germany)

Konstantin V. Sokolov, The University of Texas M. D. Anderson Cancer Center (United States)

Claudia Tortiglione, Istituto di Scienze Applicate e Sistemi Intelligenti

"Eduardo Caianiello" (Italy)

Chih-Chung Yang, National Taiwan University (Taiwan)

Junjie Zhu, Nanjing University (China)

\section{Session Chairs}

1 Biomedical Applications of Plasmonic Nanoparticles I

Jun Chen, Huashan Worldwide Medical Center (China)

3 Nano-Bio Complexes and Assemblies

Swarnapali De Silva Indrasekara, The University of North Carolina at Charlotte (United States) 
4 Biomedical Applications of Plasmonic Nanoparticles II

Divita Mathur, U.S. Naval Research Laboratory (United States)

5 Nanoparticle Characterization Techniques

Thomas Pons, Ecole Supérieure de Physique et de Chimie Industrielles de la Ville de Paris (France)

6 NP Applications in Biosensing and Bioimaging I

Emmanuel Stratakis, Foundation for Research and Technology-Hellas (Greece)

7 Biofouling and Applications in Neuroscience

Hedi Mattoussi, Florida State University (United States)

8 NP Applications in Biosensing and Bioimaging II

Halima F. Alem, Université de Lorraine (France)

9 NP Applications in Biosensing and Bioimaging III

Gianluca M. Farinola, Università degli Studi di Bari Aldo Moro (Italy)

10 Applications of Nanoparticles in Cancer Theranostics

Allison M. Dennis, Boston University (United States)

11 Multifunctional Nanoparticles for Biomedical Applications

Guillermo Acuna, Université de Fribourg (Switzerland) 